\title{
Effects of trace elements and calcium on diabetes and obesity, and their complications: Protective effect of dairy products - A mini-review
}

\author{
Dominique Bouglé*, Saïd Bouhallab, François Bureau, Gautier Zunguin \\ Centre d'Éducation Thérapeutique, Service de Pédiatrie, CH de Bayeux, 14401 Bayeux, France
}

Received 21 October 2008 - Accepted 5 February 2009

\begin{abstract}
Trace elements and minerals influence the pathogenesis of obesity and diabetes and their complications, mainly through their involvement in peroxidation and inflammation. On the other hand, peroxidation and inflammation are liable to alter the metabolism of these nutrients, which should be taken into account when assessing their status. Milk products are capable of preventing iron-induced peroxidation and the metabolic complications of the diseases. Calcium, especially cow milk calcium, seems to be capable of preventing the development of adipocytes and obesity complications (inflammation, hypertension, and insulin resistance), mainly through interactions with vitamin D metabolism. These observations give an opportunity to influence the course of obesity by dietetic advices.
\end{abstract}

calcium / trace element / iron / obesity / diabetes / peroxidation

\begin{abstract}
摘要 - 微量元素和钻在糖尿病和肥胖症及并发症中的作用:乳制品的保护作用。微量元素 和矿物质含量影响肥胖症和糖尿病及其并发症的致病机理, 主要是由于他们参与过氧化反 应和炎症的发生。另一方面, 过氧化反应和炎症有可能改变这些营养物质的代谢, 所以对 他们进行评价时, 应考虑到他们的这些作用。乳制品能够防止铁诱导的过氧化和代谢性并 发症疾病。通过与维生素 $\mathrm{D}$ 代谢的交互作用, 锎及牛乳中的钲, 似乎能够防止脂肪的增 加和肥胖并发症 (炎症、高血压、胰岛素抗药性) 的发生。这些发现给肥胖病人的饮食建议 提供了依据。
\end{abstract}

\section{钻 / 痕量元素 / 铁 / 肥胖症 / 糖尿病 / 过氧化}

Résumé - Rôle des oligo-éléments et du calcium dans les formes de diabète et l'obésité et leurs complications. Effet protecteur des produits laitiers. Les oligo-éléments et les minéraux jouent un rôle dans la genèse de l'obésité, du diabète et de leurs complications métaboliques, en particulier par leur implications dans les phénomènes inflammatoires et la peroxydation. Ces derniers pouvant modifier par eux-mêmes le métabolisme des minéraux, il faut en tenir compte dans l'appréciation de leur statut. Les produits laitiers préviennent la peroxydation liée au fer (rôle principalement joué par les protéines) et les complications métaboliques : ainsi, le calcium, surtout d'origine laitière, interagit avec la vitamine D pour prévenir la différenciation des adipocytes, la lipogenèse et favoriser la production de chaleur ; il lutte contre l'inflammation, l'hypertension et la résistance à l'insuline, composants majeurs du risque cardio-vasculaire. Ces données ouvrent la voie à une intervention non médicamenteuse, sur le long terme, des maladies de civilisation.

calcium / oligo-éléments / fer / obésité / diabète / peroxydation

*Corresponding author (通讯作者): dbougle@wanadoo.fr 


\section{INTRODUCTION}

Peroxidation and inflammation are responsible for the occurrence of metabolic complications of diabetes and obesity [22]: lipoprotein changes (hypertriglyceridemia and hypercholesterolemia) and increased blood pressure are associated with overweight and insulin resistance or diabetes in the increase of incidence of coronary heart disease.

Trace elements (TE) play a significant role in the regulation of peroxidation and inflammation [23]: free iron ( $\mathrm{Fe})$ and copper $(\mathrm{Cu})$ induce the production of free radicals. Some TE have protecting properties as cofactors of antioxidant enzymes, e.g. glutathione peroxidase (GPx) for selenium (Se) and superoxide dismutase for $\mathrm{Cu}$.

On the other hand, TE metabolism is altered by inflammation and the diseases themselves.

Some minerals and TE such as chromium $(\mathrm{Cr})$ are involved in the pathogenesis of diseases: $\mathrm{Cr}$ improves membrane transport of glucose; calcium $(\mathrm{Ca})$ influences several biochemical events involved in weight regulation, such as fat absorption and adipocyte differentiation.

The interpretation of biological data should take inflammation into account. However, the opportunity of changing the course of these widespread diseases by simple dietetic advices is exciting.

The few examples below will illustrate these complex interactions.

\section{IRON AND OBESITY: PROTECTIVE EFFECT OF MILK PRODUCTS}

First studies on Fe status in obese subjects showed a high prevalence of deficiency $[14,19]$; however, Fe status assessment only relied on plasma Fe. The measurement of tissue storage parameters of $\mathrm{Fe}$ gives far lower values [24]. Indeed, the interpretation of these data should take into account the influence of inflammation on $\mathrm{Fe}$ metabolism: inflammation increases tissue storage (assessed by ferritin dosage) at the expense of blood levels, to prevent the oxidant effects of unbound Fe. Hence, obesity-induced inflammation by itself can influence the $\mathrm{Fe}$ status $[9,21]$. Alterations in Fe metabolism are also associated with the increased oxidative stress of diabetes [10]. These relationships explain why we did not find any effect of overweight on Fe status in a population of obese children without inflammation (Tab. I).

On the other hand, we found a relationship between Fe and metabolic risk factors, independent of inflammation (Tab. II); these observations are consistent with the literature data which suggest that ferritin increase could be a marker of obesity complications, such as liver steatosis and insulin resistance, as well as of $\mathrm{Fe}$ status [6, 12, 21]. The mechanisms that are involved are, together with the oxidant effect of free $\mathrm{Fe}$, its direct stimulation of glucose transport into the adipocytes.

The protective effect of milk products on the metabolic complications of obesity or diabetes was first showed by Pereira [18], and then confirmed by several reports $[1,3,5]$.

Proteins are the best candidates with these properties [17, 28]; specifically, they prevent oxidant effects of $\mathrm{Fe}$ in gut mucosa and liver (Fig. 1).

\section{CALCIUM, DAIRY PRODUCTS, AND OBESITY}

Numerous Ca supplementation studies were performed in women to prevent menopausal osteoporosis. When revisited, their results revealed that supplemented women had gained less weight than non-supplemented women [4].

Several mechanisms can be involved: the active form of vitamin D, lalpha, 
Table I. Fe status and inflammation in control and obese children (initial data from 316 children aged $11.2 \pm 3.1(x \pm 1 \mathrm{SD})$ years, before their treatment by the obesity clinic of the pediatric department of the University Hospital of Caen).

\begin{tabular}{rrcccc}
\hline & $n$ & $\begin{array}{c}\text { Sedimentation rate } \\
(\mathrm{mm})\end{array}$ & $\begin{array}{c}\text { Fibrinogen } \\
\left(\mathrm{g} \cdot \mathrm{L}^{-1}\right)\end{array}$ & $\begin{array}{c}\text { Plasma Fe } \\
\left(\mu \mathrm{mol} \cdot \mathrm{L}^{-1}\right)\end{array}$ & $\begin{array}{c}\text { Ferritin } \\
\left(\mu \mathrm{g} \cdot \mathrm{L}^{-1}\right)\end{array}$ \\
\hline Control: BMI $z$ score $<2$ & 24 & $11.3 \pm 10.0^{*}$ & $3.5 \pm 0.8$ & $12.9 \pm 5.4$ & $39.3 \pm 16.6$ \\
BMI $z$ score 2-4 & 109 & $11.5 \pm 5.5$ & $3.6 \pm 0.7$ & $14.0 \pm 5.2$ & $39.0 \pm 21.7$ \\
BMI $z$ score 4-6 & 122 & $14.0 \pm 7.9$ & $3.7 \pm 0.8$ & $13.9 \pm 5.5$ & $43.6 \pm 23.2$ \\
BMI $z$ score 6-8 & 61 & $12.9 \pm 9.1$ & $3.7 \pm 1.5$ & $15.6 \pm 4.8$ & $43.6 \pm 37.3$ \\
ANOVA & & $\mathrm{NS}$ & $\mathrm{NS}$ & $\mathrm{NS}$ & $\mathrm{NS}$ \\
\hline
\end{tabular}

BMI: body mass index (weight $(\mathrm{kg}) /$ height $\left.(\mathrm{m})^{2}\right)$.

NS: not significant.

$* x \pm 1 \mathrm{SD}$.

Table II. Multivariate regression analysis between $F$ status and metabolic risk factors in obese children, using inflammation markers as covariables (same patients as in Tab. I).

\begin{tabular}{lrccc}
\hline & $P$ & Sedimentation rate & Ferritin & Transferrin \\
\hline Diastolic blood pressure & $<0.001$ & $0.002^{*}$ & 0.018 & 0.030 \\
LDL-cholesterol & 0.002 & & & 0.011 \\
Triglycerides & $<0.001$ & & & 0.009 \\
\hline
\end{tabular}

Insulin resistance and HDL cholesterol did not enter the model.

$* x \pm 1$ SD.

25-dihydroxycholecalciferol, leads to in vitro adipocytic differentiation in a dose-dependent manner; it stimulates adipocyte lipogenesis by fatty acid synthase, inhibits lipolysis, and increases the storage of triglycerides $[25,26]$. It also inhibits the activity of uncoupling protein 2 , which increases thermogenesis [20]. Therefore, the suppression of 1alpha,25-dihydroxycholecalciferol synthesis using dietary $\mathrm{Ca}$ has a protective effect against obesity. Dietary $\mathrm{Ca}$ also forms insoluble soaps with saturated fatty acids, and decreases fat absorption.

In addition, $\mathrm{Ca}$ could prevent the occurrence of obesity-related diseases, hypertension, and insulin resistance, through its interactions with vitamin D: 1alpha,25dihydroxycholecalciferol is a positive regulator of insulin secretion by pancreatic $\beta$ cells and is also involved in peripheral insulin sensitivity, through the vitamin D receptor. In addition, it stimulates $\mathrm{Ca}$ influx in vascular smooth muscle cells and increases vascular peripheral resistance, which can contribute to increased blood pressure; it increases oxidative stress and inflammatory stress. Suppression of 1alpha,25-dihydroxycholecalciferol by $\mathrm{Ca}$ decreases oxidative and inflammatory stress in vivo, and has a relaxing effect on smooth fibers of vascular muscle [25-27].

In human studies, $\mathrm{Ca}$ supplementation of obese patients gave conflicting results $[8,11]$; these results can be analyzed as follows: $\mathrm{Ca}$ is not a drug, but a nutrient whose intake is only beneficial at physiological levels of intakes; Ca supplementation helps loosing weight, when basal intakes are low, and when it is associated with a hypocaloric diet.

Dairy products contain additional factors that could enhance the metabolic effects of 


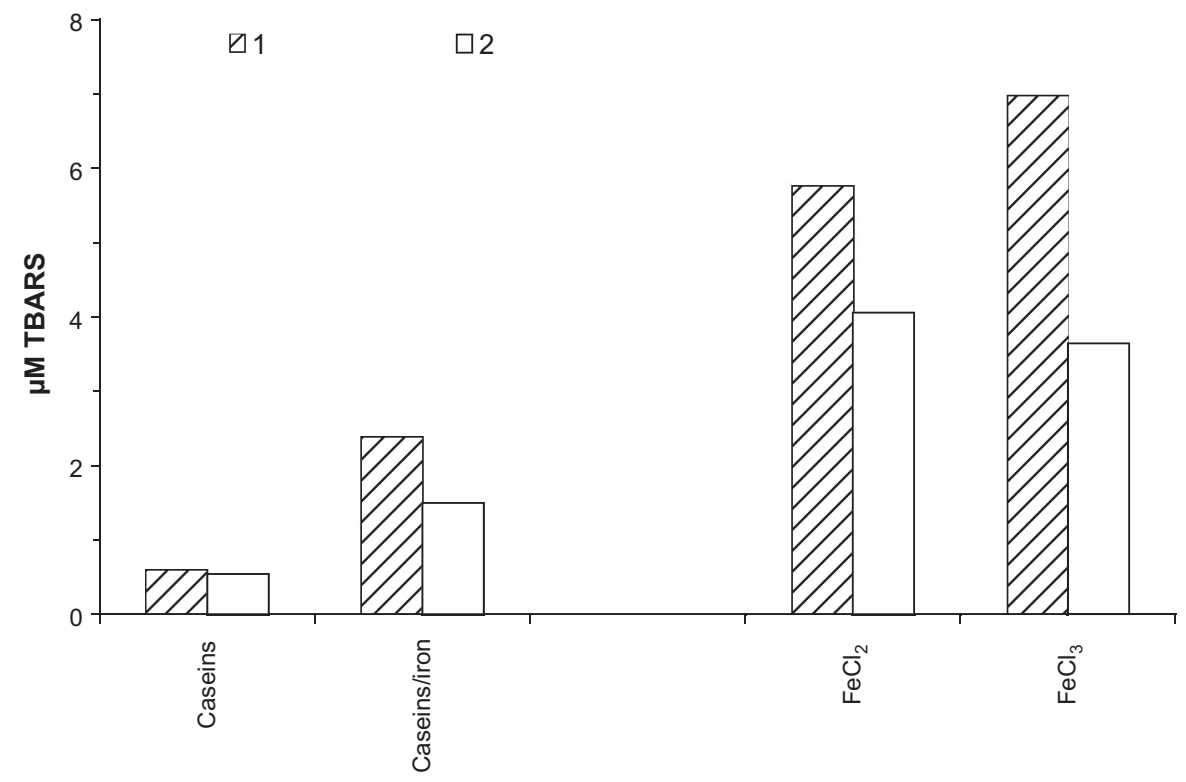

Figure 1. In vitro assessment of the protective effect of casein (free or bound to iron) against ironinduced peroxidation of liposomes (adapted from reference [15]). TBARS - 2-thiobarbituric acid reactive substances: (1) $3.3 \cdot 10^{-4} \mathrm{~mol} \cdot \mathrm{L}^{-1}$ of iron either free or in its complexed form and $8.4 \cdot 10^{-5} \mathrm{~mol} \cdot \mathrm{L}^{-1}$ of caseins, (2) $1.6 \cdot 10^{-4} \mathrm{~mol} \cdot \mathrm{L}^{-1}$ of iron and $4.2 \cdot 10^{-5} \mathrm{~mol} \cdot \mathrm{L}^{-1}$ of caseins; (1) vs. (2): $P<0.05$ for caseins/iron, $\mathrm{FeCl}_{2}$, and $\mathrm{FeCl}_{3}$. ANOVA: $P<0.05 ; t$ tests: caseins $<$ caseins/ iron $<\mathrm{FeCl}_{2}$ and $\mathrm{FeCl}_{3}$.

Ca: for example, some trans isomers of fatty acids such as conjugated linoleic acid, or angiotensin-converting enzyme inhibitors, which can contribute to the antihypertensive properties of dairy products $[11,27]$.

\section{TRACE ELEMENTS AND DIABETES}

\subsection{Chromium}

In vitro, $\mathrm{Cr}$ significantly enhances glucose uptake in skeletal muscle cells and enhances glucose disposal. The $\mathrm{Cr}$ status of diabetics is poor: urine excretion is increased and plasma levels are low. Positive outcomes from $\mathrm{Cr}$ supplementation included reduced blood glucose, insulin, glycated hemoglobin (which reflects diabetes control of previous weeks), cholesterol, and triglyceride levels and reduced requirements for hypoglycemic medication. Most of these studies used $\mathrm{Cr}$ picolinate because of its bioavailability $[2,7]$.

\subsection{Selenium, copper, and zinc}

Diabetic patients have a decreased antioxidant capacity, resulting in an increased excretion of malondialdehyde which is a degradation product of unsaturated fatty acids. Alterations of TE metabolism could be involved in the oxidative stress of diabetes, such as of Fe: urine excretion of zinc $(\mathrm{Zn})$ and $\mathrm{Cr}$ is increased. The activity of antioxidant enzymes, specifically GPx whose cofactor is Se, is decreased [10, 16].

Therefore, one could have expected a beneficial effect of Se supplementation 
in diabetic patients; most trials, conducted in Se-replete populations, found no evidence of cardiovascular protection. Chronically increased $\mathrm{Se}$ intake in Se-replete populations can induce diabetes and may be also induce hypercholesterolemia. If adequate Se intake is needed to maximize the activity of GPx and other selenoproteins, its narrow safety margin makes the supplementation hazardous [15].

Zinc is involved in the metabolism of adipose tissue: it regulates leptin secretion, which informs the brain on the level of fat storage; it enhances the release of free fatty acids and glucose uptake; however, clinical studies did not find consistent correlations between $\mathrm{Zn}$ concentrations and adiposity or leptin [13]. $\mathrm{Zn}$ is also involved in glucose regulation and lessens insulin concentrations, but $\mathrm{Zn}$ supplementation does not prevent the occurrence of diabetes.

\section{CONCLUSIONS}

Relationships of TE and minerals with obesity or diabetes are complex: alterations of their metabolism can be induced by the diseases and their complications, but they also can contribute to the aggravation of the diseases. These relationships are mediated by inflammation and peroxidation events.

Several components of milk products explain their protective effect on the development of obesity, and on its complications; they mainly involve protection against peroxidation and interactions with vitamin D. These observations explain why the consumption of dairy products is usually associated with a low incidence of obesity and its metabolic complications.

\section{REFERENCES}

[1] Azadbakht L., Mirmiran P., Esmaillzadeh A., Azizi F., Dairy consumption is inversely associated with the prevalence of the meta- bolic syndrome in Tehranian adults, Am. J. Clin. Nutr. 82 (2005) 523-530.

[2] Balk E.M., Tatsioni A., Lichtenstein A.H., Lau J., Pittas A.G., Effect of chromium supplementation on glucose metabolism and lipids: a systematic review of randomized controlled trials, Diabetes Care 30 (2007) 2154-2163.

[3] Choi H.K., Willett W.C., Stampfer M.J., Rimm E., Hu F.B., Dairy consumption and risk of Type 2 diabetes mellitus in men, Arch. Int. Med. 165 (2005) 997-1003.

[4] Davies K.M., Heaney R.P., Recker R.R., Lappe J.M., Barger-Lux M.J., Rafferty K., Hinders S., Calcium intake and body weight, J. Clin. Endocrinol. Metab. 85 (2000) 4635-4638.

[5] Ferrieres J., Bongard V., Dallongeville J., Simon C., Bingham A., Amouyel P., Arveiller D., Ducimetiere P., Ruidavets J.B., Consommation de produits laitiers et facteurs de risque cardiovasculaire dans l'étude Monica, Cah. Nutr. Diet. 41 (2006) 33-38.

[6] Forouhi N.G., Harding A.H., Allison M., Sandhu M.S., Welch A., Luben R., Bingham S., Khaw K.T., Wareham N.J., Elevated serum ferritin levels predict new-onset type 2 diabetes: results from the EPIC-Norfolk prospective study, Diabetologia 50 (2007) 949-956.

[7] Hummel M., Standl E., Schnell O., Chromium in metabolic and cardiovascular disease, Horm. Metab. Res. 39 (2007) 743-751.

[8] Lanou A.J., Barnard N.D., Dairy and weight loss hypothesis: an evaluation of the clinical trials, Nutr. Rev. 66 (2008) 272-279.

[9] Lecube A., Carrera A., Losada E., Hernandez C., Simo R., Mesa J., Iron deficiency in obese postmenopausal women, Obes. Res. 14 (2006) 1724-1730.

[10] Luan de C., Li H., Li S.J., Zhao Z., Li X., Liu Z.M., Body iron stores and dietary iron intake in relation to diabetes in adults in North China, Diabetes Care 31 (2008) 285-286.

[11] Major G.C., Chaput J.P., Ledoux M., St-Pierre S., Anderson G.H., Zemel M.B., Tremblay A., Recent developments in calcium-related obesity research, Obes. Rev. 9 (2008) 428-445.

[12] Mandato C., Lucariello S., Licenziati M.R., Franzese A., Spagnuolo M.I., Ficarella R., Pacilio M., Amitrano M., Capuano G., Meli R., Vajro P., Metabolic, hormonal, oxidative, 
and inflammatory factors in pediatric obesity-related liver disease, J. Pediatr. 147 (2005) 62-66.

[13] Marreiro Ddo N., Fisberg M., Cozzolino S.M., Zinc nutritional status and its relationships with hyperinsulinemia in obese children and adolescents, Biol. Trace Elem. Res. 100 (2004) 137-150.

[14] Moayeri H., Bidad K., Zadhoush S., Gholami N., Anari S., Increasing prevalence of iron deficiency in overweight and obese children and adolescents (Tehran adolescent obesity study), Eur. J. Pediatr. 165 (2006) 813-814.

[15] Navas-Acien A., Bleys J., Guallar E., Selenium intake and cardiovascular risk: what is new?, Curr. Opin. Lipidol. 19 (2008) 43-49.

[16] Ozata M., Mergen M., Oktenli C., Aydin A., Sanisoglu S.Y., Bolu E., Yilmaz M.I., Sayal A., Isimer A., Ozdemir I.C., Increased oxidative stress and hypozincemia in male obesity, Clin. Biochem. 35 (2002) 627-631.

[17] Parodi P.W., A role for milk proteins and their peptides in cancer prevention, Curr. Pharm. Des. 13 (2007) 813-828.

[18] Pereira M.A. Jr., Jacobs D.R., Van Horn L., Kartashov A.I., Ludwig L.S., Dairy consumption, obesity, and the insulin resistance syndrome in young adults. The CARDIA study, JAMA 287 (2002) 2081-2089.

[19] Pinhas-Hamiel O., Newfield R.S., Koren I., Agmon A., Lilos P., Phillip M., Greater prevalence of iron deficiency in overweight and obese children and adolescents, Int. J. Obes. Relat. Metab. Disord. 27 (2003) 416-418.

[20] Shi H., Norman A.W., Okamura W.H., Sen A., Zemel M.B., 1 1 ,25-dihydroxyvitamin $\mathrm{D}_{3}$ inhibits uncoupling protein 2 expression in human adipocytes, FASEB J. 16 (2002) $1808-1810$.
[21] Vari I.S., Balkau B., Kettaneh A., André P., Tichet J., Fumeron F., Caces E., Marre M., Grandchamp B., Ducimetière P., DESIR study group, ferritin and transferrin are associated with metabolic syndrome abnormalities and their change over time in a general population: data from an epidemiological study on the insulin resistance syndrome (DESIR), Diabetes Care 30 (2007) 1795-1801.

[22] Vincent H.K., Taylor A.G., Biomarkers and potential mechanisms of obesity-induced oxidant stress in humans, Int. J. Obes. 30 (2006) 400-418.

[23] Wintergerst E.S., Maggini S., Hornig D.H., Contribution of selected vitamins and trace elements to immune function, Ann. Nutr. Metab. 51 (2007) 301-323.

[24] Yanoff L.B., Menzie C.M., Denkinger B., Sebring N.G., McHugh T., Remaley A.T., Yanovski J.A., Inflammation and iron deficiency in the hypoferremia of obesity, Int. J. Obes. Lond. 31 (2007) 1412-1419.

[25] Zemel M.B., Calcium modulation of hypertension and obesity: mechanisms and implications, J. Am. Coll. Nutr. 20 (2001) 428S-435S.

[26] Zemel M.B., Regulation of adiposity and obesity risk by dietary calcium: mechanisms and implications, J. Am. Coll. Nutr. 21 (2002) 146S-151S.

[27] Zemel M.B., Sun X., Dietary calcium and dairy products modulate oxidative and inflammatory stress in mice and humans, J. Nutr. 138 (2008) 1047-1052.

[28] Zunquin G., Rouleau V., Bureau F., Bouhallab S., Theunynck D., Rousselot P., Arhan P., Bouglé D., Iron and exercise induced alterations in antioxidant status: protection by dietary milk proteins, Free Rad. Res. 40 (2006) 535-542. 